\title{
Music in Perumah Begu Ritual of Karo Tribe (Study of Form and Music Functions)
}

\author{
Esra Pt Siburian \\ Lecturer of Music Education Study Program at State University of Medan, Indonesia \\ b4khrul.4m4l@gmail.com
}

\begin{abstract}
This study wants to examine the phenomenon of the ritual of summoning the spirits of people who have died in the Karo community which involves the presence of musical sounds in the stages of the procession. What is interesting in this case is how the form of ritual, and the form of music used in accompanying each stages of the procession of Perumah Begu rituals will be studied in depth. The method used in this study is descriptive qualitative, that are the steps to make field research, interviews, studio work, and analyze data. Techniques of analysis data are carried out by the process of systematically analyzing and compiling data that obtained from interviews, field research, and studio work, then conducting data sections and organizing data into categories, describing them into units, synthesizing, arranging into patterns, choose which ones are important, and will be studied, and make conclusions so that they are easily understood by themselves and others. Based on the study, it can be concluded that the findings are as follows: 1) Perumah Begu's ritual is a culture of summoning spirits or ghosts of deceased people to solve problems with their families that have not been completed until the day of his/her death. This ritual was carried out on the first night after the body was buried. This ritual is led by a shaman or (guru si baso) as a media that can mediate between the spirit world and the human world. The implementation is divided into three stages: the preparation, implementation and closing. 2) The musical accompaniment used in the Perumah Begu's ritual is the gendang lima sendalanen ensembles. In general, the gendang lima sendalanen ensembles is known by three forms of reportoar known as: a) Simalungun rayat b) Odak-odak, c) Patam-patam. 3) The connection of the three forms of music reportoar above are very binding on Perumah Begu's ritual journey from the beginning to the end. Each form has its role and function in the Perumah Begu's ritual that is carried out by the Karo community.
\end{abstract}

Keywords : Music Function; Perumah Begu Ritual; Karo Tribe

\section{Introduction}

Karo tribe is one of several Batak sub-tribes in North Sumatra. Karo is also a term for one administrative region of the Regency, namely Karo Regency, which covers the entire Karo plateau. The area inhabited by the Karo tribe is bordered to the east by a roadside that separates the plateau from Serdang. In the south it is roughly bounded by the Biang river (which is named the Wampu river, when it enters Langkat), in the west it is bordered by Mount Sinabung and the north the area extends to the low flats of Deli and Serdang. The typical name for Karo Regency is Taneh Karo Simalem, which indicates that the Karo Regency is fertile's land, has cool mountain air. Because of its natural fertility, many Karo people make agriculture as their work.

Karo ethnic groups have beliefs about the existence of magical powers or spirit realms that are always related to their life cycle. This is evidenced by the many mystical rituals carried out in the lives of the Karo people. Some of the rituals or ceremonies are: ceremonies commemorating birth, ceremonies ahead of adulthood, marriage ceremonies, ceremony related to the processing of land / plants, ceremonies rejecting reinforcements / bringing in profits, ceremonies related to the house, until the memorial service of death. All the ceremonial 
activities of this tradition from the birth ritual to the ritual of death are always performed by presenting the accompaniment of traditional Karo music.

An interesting phenomenon to be understood is that there is a ritual of summoning the spirit of a deceased person to resolve a problem that has not been resolved during that person's life with his relatives. For this reason, the Karo community believes that this can be done by recalling the spirit of the deceased person and completing the unfinished cases. And more unique is this ritual involves the presence of music in the stages of the process. This ritual of calling a deceased spirit is known as the Perumah Begu ritual (calling of the spirit / ghost) of a deceased person. How the shape and function of music in house rituals becomes the focus of this study.

The Perumah Begu ritual is a relic of the Karo beliefs of the Karo people in the past, and is still being carried out and is believed to be an important part of the circle of life of the Karo people. The house-to-house ritual is one form of ritual memorial for the dead. This ritual is usually performed on the first night after the body of a deceased person is buried. The house rituals in the implementation are led by a shaman or they called guru si baso. During the ritual house procession, the shaman (si baso) plays two important roles, namely as the 'master of ceremony' or the main leader of the ritual and also acts as 'story teller in dramatically ritual'. The meatball as the storyteller of the life story of a recently deceased person. Si baso can only retell the life story of someone who has just died with a trance. This entire series also presents traditional Karo music ensembles. What is interesting here is how the form of perumah begu in the Karo community and how the form of music that accompanies the rituals of the house of dumb will be studied in depth in this study.

\section{Research Method}

The method used in this study is descriptive qualitative, that are the steps to make field research, interviews, studio work, and analyze data. Techniques of analysis data are carried out by the process of systematically analyzing and compiling data that obtained from interviews, field research, and studio work, then conducting data sections and organizing data into categories, describing them into units, synthesizing, arranging into patterns, choose which ones are important, and will be studied, and make conclusions so that they are easily understood by themselves and others.

\section{Discussion}

\subsection{The Form of House Ritual is Like that in Karo Society}

The ritual of perumah begu is a continuation of the burial ritual of a deceased person, in the settlement of the problem that has not been resolved during his lifetime. This is a necessity made by the Karo people who still adhere to animist beliefs to respect the culture of the ancestors of the Karo people. In performing this ritual, it is usually done the first night after the body is buried. This ritual is led by a shaman or (guru si baso). During the procession of the house procession, the shaman ( si baso) served as the storyteller of the life story of a recently deceased person. All life stories of people who have died will be retold by si baso after being in a state of trance or possessed by the spirit of a deceased person. In a state of trance or in the state of being entered into the spirit of a deceased person (the meatball) will tell about the person who has died. The story presented can be grouped in three parts. First about the spirit 
person of the deceased, the story between spirit and relatives or family, and about the hopes of the spirit after he leaves his life and towards the spirit realm.

The atmosphere in the ritual goes according to the story done by si baso in a trance. In observing the researchers the atmosphere can be very sad and sometimes exciting, the atmosphere is going very dramatically. Si baso in carrying out their role as spirits of the deceased occasionally sing sad songs because of the hope that has not been achieved during life and occasionally chants joyful joy because of a hope that is good for the spirit and for the family left behind. To resolve unresolved issues between spirits and living families, communication is carried out through the body of si baso as an intermediary between them. In this ritual the spirit inside of si baso will convey all his complaints to family members and family members present begging for good to those left behind. After the spirit finished communicating with the family that was still alive, and after all felt satisfied, si baso returned to sing happily. These singing expressions are in the form of expressions of excitement because the problem that was previously unresolved is believed to have been resolved through the house-beguiling ritual.

Si baso who are considered as intermediaries between the human world and the world of spirits have social responsibility in meeting the spiritual needs of the Karo people. Si baso are considered to be the connoisseurs of the feeling between humans and Dibata la idah (Lord of the invisible universe). As a person who is considered to master the knowledge of the spirit cosmology of the spirit, si baso can be functions as a consulting firm about the meaning of dreams, or occult events that afflict someone. If something magical happens that happens within the scope of a close relative, si baso will suggest holding perumah begu like that at night by only involving the closest relatives. In addition to maintaining a balance in mankind with the supernatural world, indirectly si baso also plays a role in maintaining the balance of the running of the norms and values of Karo customs.

\subsection{The Stages of Perumah Begu Rituals}

1. Preparation Stage

In the preparation stage several things are done:

-Picking up a shaman (Guru sibaso) that must be carried out by the outpatient party ((anak beru) by carrying a container of betel leaf and its contents. The contents of the container are:

$\circ$ The best and perfect of betel leaf

- The best tobacco

- Gambir fruit

- Betel chalk.

- After si baso (shaman) teachers are present at the intended ritual site given traditional food dishes such as.

- Belo cawir (betel leaf and tobacco of good quality)

- Cimpa (traditional Karo cake made from sticky rice flour, brown sugar and coconut milk mixed.

○ Coconut.

- Shroud (white cloth that is usually used as a wrapping body)

- Prepared ensemble drum five sedalanen consisting of five traditional Karo musical instruments. 


\section{Ritual Implementation Stage}

After all the conditions required for the perumah begu rituals are ready, si baso asks the ritual readiness, including all the requirements to the family and the perumah begu ritual is starting with prayer. Furthermore, with the accompaniment of music while eating betel leaves, guru sibaso began to move and beat the white cloth that decomposes long. The accompaniment of the five sendalanen drums continued to carry out the movement of si baso who continued to dance, as if he did not care about the people around him. Sometimes he jumps up and down and moves his arms and eyes to the sky, this condition goes on until si baso experience trance or possessed spirits. After he threw si baso to the point of being possessed, he began to portray himself as the spirit of a deceased person. In this condition guru sibaso conveyed all the words that became the will of the spirit. So this is where communication begins in solving any problem that becomes a problem between spirit and his family until it is finished.

\section{Stage of Closing Rituals}

The closing phase ends with the delivery of the final messages of the spirit to the living family through the meatball grur and closes with the end of the musical accompaniment to the activity of the sibaso teacher. After that Teacher sibaso returned to sit and suck tobacco the sign of the ritual was over. After the program was finished, the sibaso teacher was returned to his home with a thank you in the form of an honorarium which was deemed appropriate to be given to a traditional healer in addition to giving some customary items as a complement to the ritual to be taken home such as:

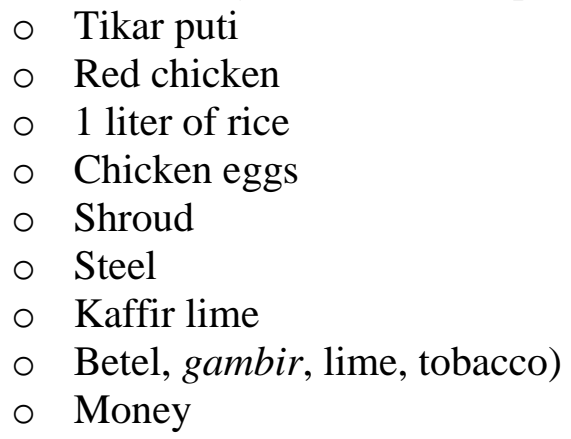

\subsection{Forms music in the ritual of Perumah Begu}

\section{- Musical instruments used}

The presentation of music in the Perumah Begu ritual is in the form of an ensemble of Gendan lima sedalanen. This ensemble consists of five musical instruments played together not to be separated. The five instruments are:

1. Sarune

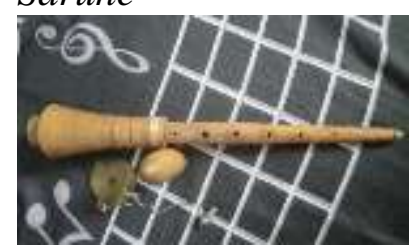

2. Singindungi Drum 


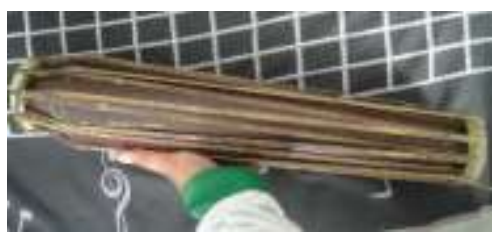

3. Singanaki Drum

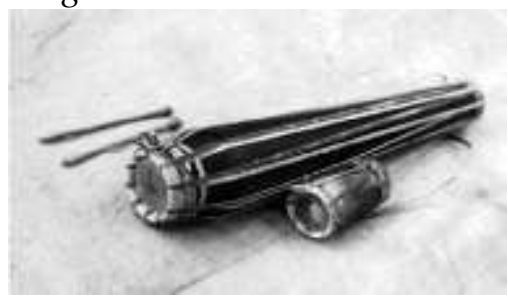

4. Penganak

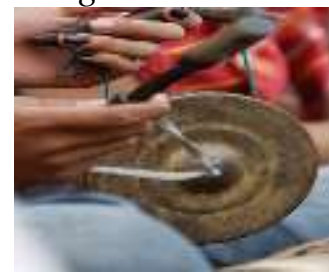

5. Gung

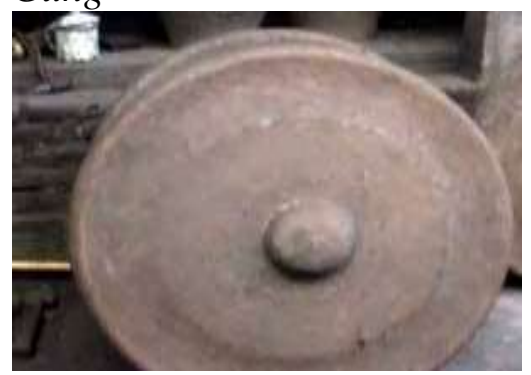

\section{- Form of Music}

The musical accompaniment used in the Perumah Begu ritual is the five sedalanen drum ensemble. In general, in the five sendalanen drum ensembles it is known that there are three forms of reporto which are characteristic of the five sendalanen drum ensembles in particular, the forms are:

1. The shape of Simalungun rayat is the slowest tempo in the five sendalanen drum ensembles. Count the number and the child at the count of -8 and count to 4 . The feeder counts to 4 and the number at the count of 8 , this count is done repeatedly until the ending.

Example:

Information:

: Beat

: Penganak

: Gung 
2. The form of Odak - odak, is the medium tempo (moderato). Beat of gung and pengakak on the beat of 2 and 4 . Penganak at beat of 2 while gung on beat of 4 . Example: ${ }^{\circ} \square^{\circ} \square$ $\begin{array}{lll}\text { Information: } \quad & \circ & \text { : Beat } \\ & \square \quad & \text { : Penganak } \\ & \square \quad & \text { : Gung }\end{array}$

3. The form of patam - patam is a fast tempo (allegro). Beat gung and pengakak on the beat of 1 and 2. Penganak at beat of 1 while gung on beat of 2 .

Example:

$\begin{array}{lll} & \square \square & \\ \text { Information: } \quad{ }^{\circ} & \text { : Beat } \\ & \square \quad & \text { : Penganak } \\ & \square \quad \text { : Gung }\end{array}$

The connection of the three forms of music reportoar above is very binding on Perumah Begu's ritual journey from the beginning to the end. In the early part of the ritual of Perumah Begu the accompaniment of music used must be in the form of Simalungun Rayat to slowly bring the duty of si baso to summon the spirit of the deceased person. This form is played repeatedly until the ghost spirit enters the body of si baso. Then after the ghost spirit enters si baso, it is continued with the accompaniment of the form of odak - odak that indicates the spirit has entered the body of si baso. Music accompaniment will be stopped when there is communication or conversation between spirits through si baso with the family. When the spirit condition is happy, the accompaniment of music is the form of patam-patam and odak - odak depending on the situation that occurs when the ritual is taking place. The following are excerpts of three forms of music in the form of musical notation.

The footage of partitur / reportoar of five drums sendalanen:

1. Simalungun Rayat

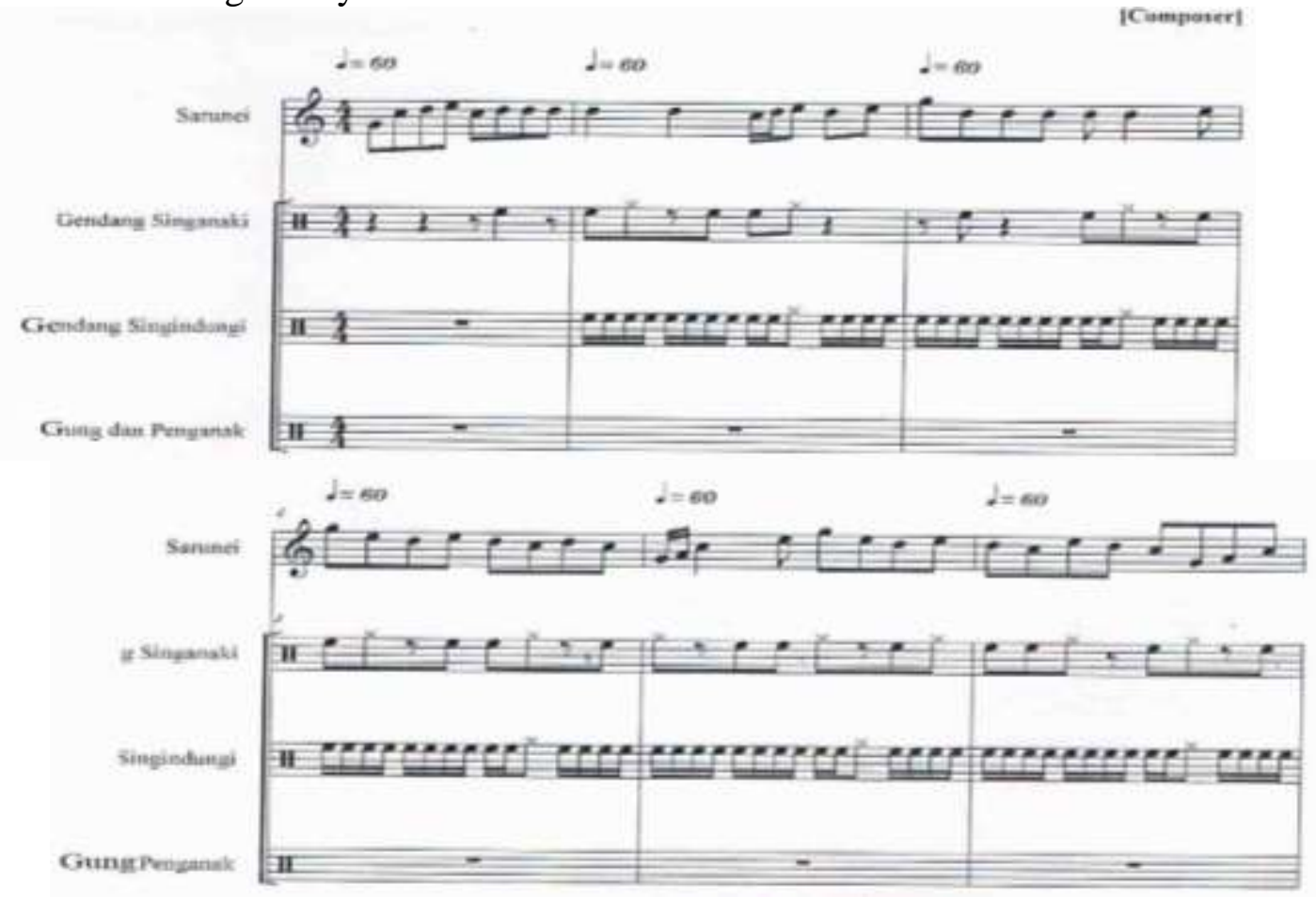


2. Odak-odak

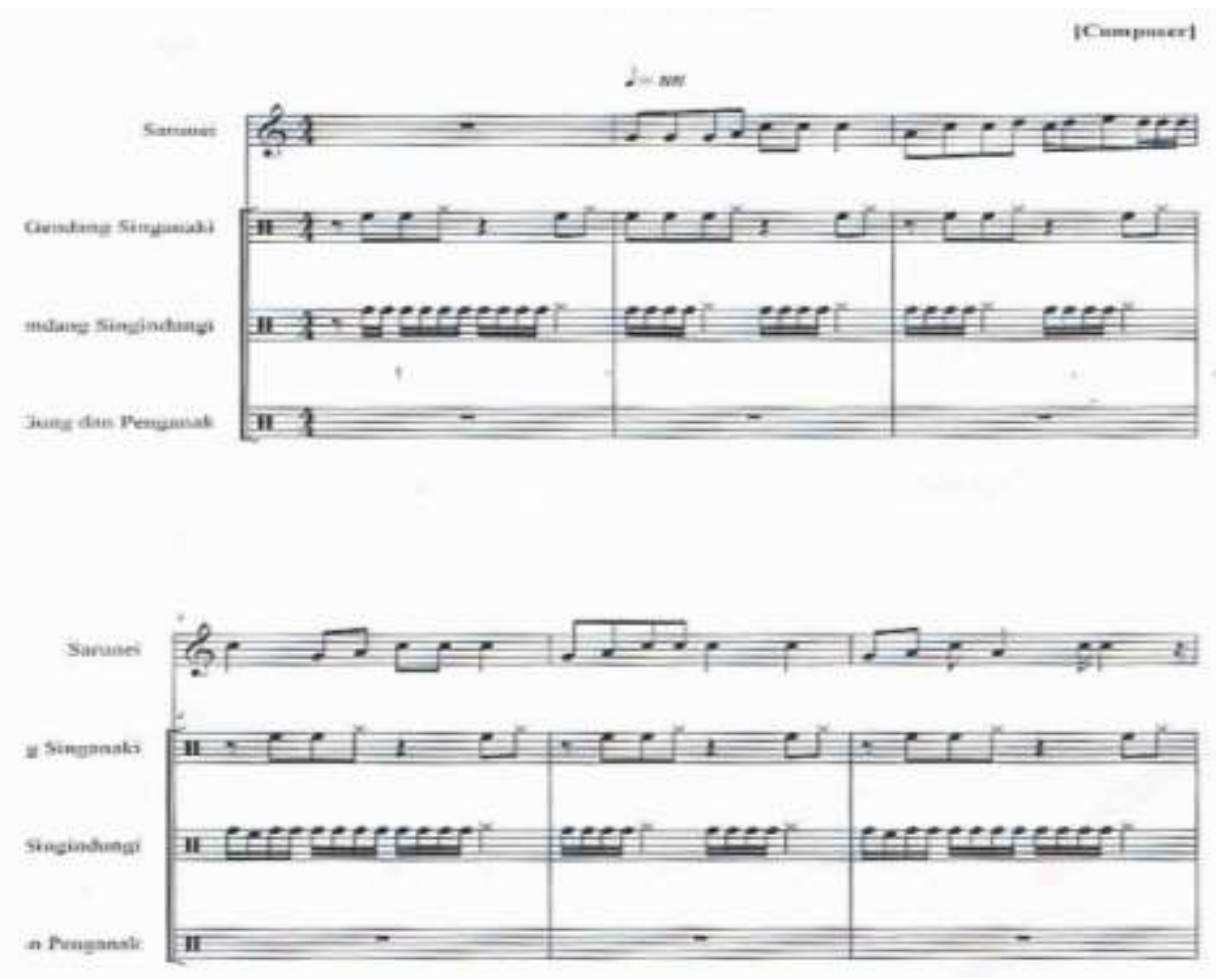

3. Si Guru Drum
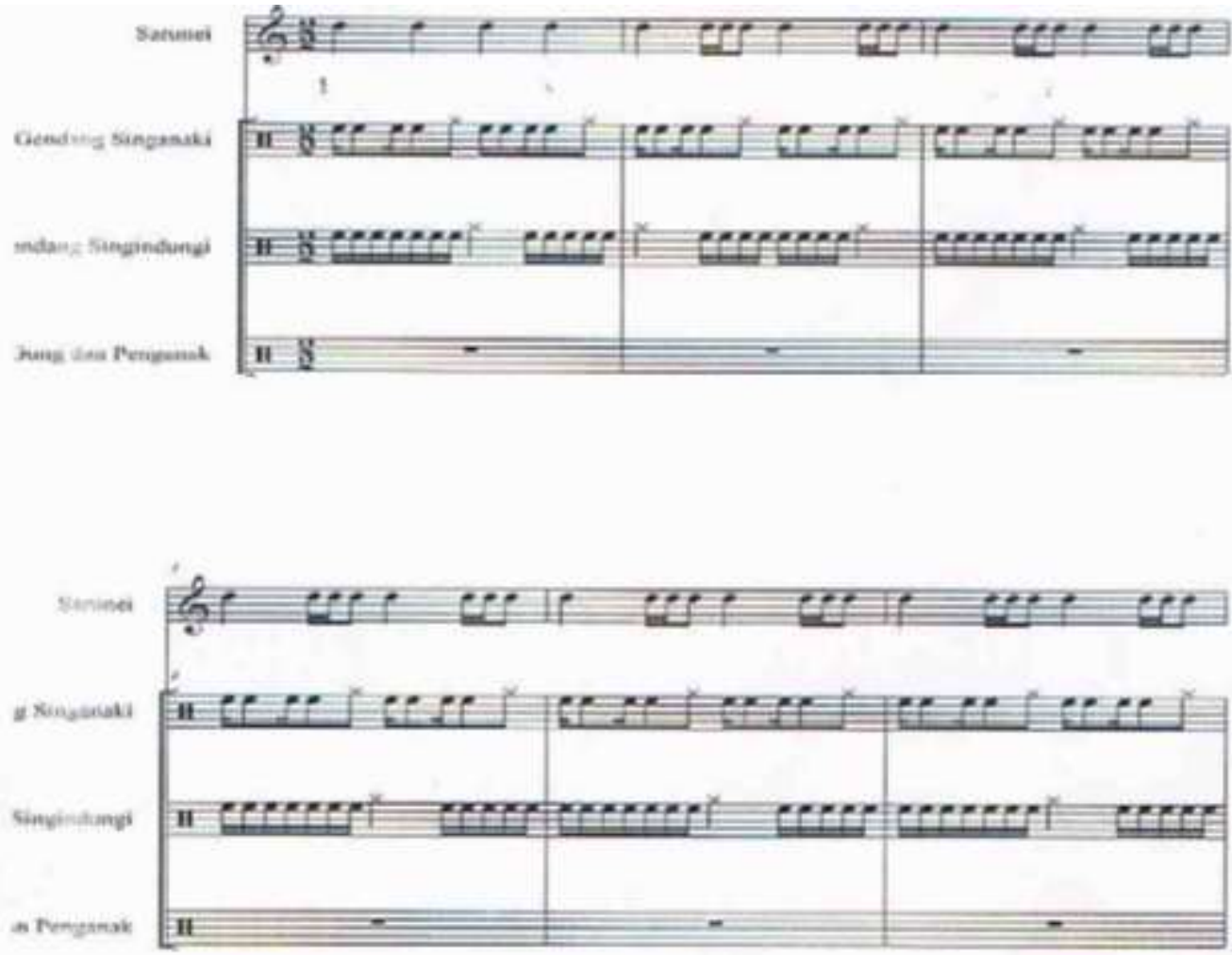


\section{Conclusion}

Based on the study, it can be concluded that the findings are as follows:

1. Perumah Begu's ritual is a culture of summoning spirits or ghosts of deceased people to solve problems with their families that have not been completed until the day of his/her death. This ritual was carried out on the first night after the body was buried. This ritual is led by a shaman or (guru si baso) as a media that can mediate between the spirit world and the human world. The implementation is divided into three stages: the preparation, implementation and closing.

2. The musical accompaniment used in the Perumah Begu's ritual is the gendang lima sendalanen ensembles. In general, the gendang lima sendalanen ensembles is known by three forms of reportoar known as: a) Simalungun rayat b) Odak-odak, c) Patampatam.

3. The connection of the three forms of music reportoar above are very binding on Perumah Begu's ritual journey from the beginning to the end. Each form has its role and function in the Perumah Begu's ritual that is carried out by the Karo community.

\section{References}

Bangun, Tridah. 1989 Adat Budaya Karo di Sumatera Utara.

Ginting, EF. 1999. Religi Karo (Membaca ReligiKaro Dengan Mata Yang Baru). Kabanjahe: Abdi Karya

Marshall, Gretchen B Rossma. 1995. Designing Qualitative Research. London: Sage Publications, Internasional Education and Professional Publisher.

Maryaeni, 2005. Metode Penelitian Kebudayaan. Jakarta: Bumi Aksara.

Sarjani, Tarigan.2011. Kepercayaan Orang Karo Tempo Doeloe.

Sugiyono, 2005. Memahami Penelitian Kualitatif. Bandung: Alfabeta.

Tarigan, Henry.1990. Percikan Budaya Karo.

Tarigan, Perikuten, 2004. Pluralitas Musik Etnik: Batak Toba, Mandailing, Melayu, Pak-pak Dairi, Angkola, Karo Dan Simalungun: Pusat Dokumentasi Dan Pengkajian Kebudayaan Batak HKBP NOMMENSEN. 